\title{
Transitional justice and human rights in
}

\section{Afghanistan*}

\author{
BARNETT R. RUBIN
}

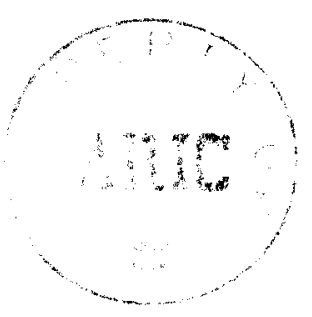

Since the defeat of the Taleban and signing of the Bonn Agreement on 5 December 2001, Afghanistan has begun what many hope will turn out to be a transition from war to peace, from chaos to order, from an unjust order and unjust disorder to a new kind of order, where all may seek justice and live in security. During such a phase, nations and international actors confront the challenge of 'transitional justice': measures by which a society accounts for past abuses as it moves from a condition of dictatorship or conflict, where the perpetrators of violence enjoy impunity, to one of civil peace, where the state seeks to provide justice and security to its citizens.

If post-transition justice is routine, transitional justice cannot be; it is exceptional. It cannot punish or even record all abuses according to the ordinary law of peacetime. This can be mathematically proved in respect of $R$ wanda, where the number of accused participants in genocide, the most serious crime known to humanity, exceeds the capacity of any known court system to try them. The people of Afghanistan have suffered a decades-long succession of crimes that constitute a virtual catalogue of all that is supposedly forbidden, but remains prevalent, in human affairs.

We should not romanticize Afghanistan before the communist conp d'état of April 1978. Afghan prisons were punishing, and the interrogators might have been surprised to learn that all Afghan constitutions since 1923 had prohibited the use of torture. The police could be corrupt and brutal. But the revolution of I 978 brought about an intensity and scope of violence that had not been seen at

* This article is a revised version of the Anthony Hyman Memorial Lecture, delivered at the School of Oriental and African Studies, University College London, on 3 February 2003. Anthony Hyman, a writer and commentator, died in December 1999 at the age of 53 after a long illness. Hyman, author of Afghanistan under Sovict domination (first published by Macmillan in 1982), had a long-term commitment to the human rights and welfare of the people of Afghanistan, which he manifested in his scholarly writing, his journalistic comnertary, and in his participation in the Afghan Refugee Information Network. He also served on the editorial board of Central Asian Survey, and wrote extensively on that region as well. The School of Oriental and African Studies, where Hynan studied and occasionally lectured, held a widely attended memorial meeting for Hyman in February 2000 . Soon after that event, Hyman's friends and colleagues decided to establish an annual lecture in his memory and invited Barnett $R$. Rubin, a friend and colleague of Hyman, to deliver the first lecture in his memory.

Intemational Affairs 79, $3(2003) 567-581$ 
least since the formation of the modern Afghan state in the closing years of the nineteenth century.

From April 1978 to December I979, the Khalqi faction's communist regime attempted to eradicate its enemies through mass arrests and executions. The regime subsequently installed by the Soviet Union, dominated by the Parchami faction, published a list of about 12,000 people said to have disappeared in Pul-i Charkhi prison under Khalqi rule. Others put the actual figure higher. Throughout the country, the Khalqi regime, at times with the apparent complicity of Soviet advisers, executed an unknown number - probably in the tens of thousands - of religious, tribal and clan leaders. In a few cases, people were buried or burned alive. After a military mutiny led by Captains Ismail Khan and Alauddin Khan, the city of Herat was bombed indiscriminately, with thousands of casualties.

During the Soviet occupation, hundreds of thousands of civilians, possibly a million or more, lost their lives in the indiscriminate bombing and shelling of villages thought to be sheltering the resistance. Populated areas by roadsides were razed. Millions became refugees. Irrigation systems, orchards, and grain and seed storage were destroyed. Torture became part of an intelligence effort and hence more systematic, with the aid of Soviet and East German advisers. A diplomat of the regime once estimated to me that i 50,000 people had been arrested in Kabul by his government, and virtually all prisoners were tortured.

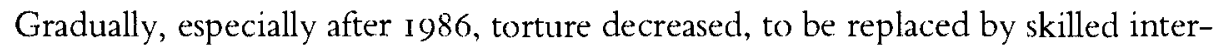
rogation. Indiscriminate bombing decreased, to be replaced by indiscriminate bribing. But debasement of the currency is not yet classified as a war crime.

As both the mujahidin resisting the regime and the loosely controlled tribal militias fighting for it gained in strength, so their abuses also increased. Since fleeing to Pakistan in the I970s some mujahidin leaders, notably Gulbuddin Hikmatyar, had assassinated others. Their turf wars in Afghanistan also proved brutal for civilians. The treatment of prisoners by guerrilla irregulars has never been one of the bright spots in the history of warfare, and this conflict was no exception: one even heard of captured Soviet soldiers being skinned alive, though some were allowed visits by the International Committee of the Red Cross, after the regime agreed to give it access in 1986. With US and Pakistani supplies and direction, mujahidin in the late I980s began to rocket the city of Kabul indiscriminately, killing and mutilating many civilians. The Arab extreme Islamists brought with them their own brutal doctrines of warfare, advocating the execution of 'communist' civilian men and the capture or trafficking of their women.

When the Soviet-installed leader Najibullah fell in April I992, the country entered a period of virtual statelessness, in which ethnic antagonisms increased. While the Soviet war destroyed the countryside, the war among the mujahidin and militias destroyed the capital, killing tens of thousands of people. The destruction of entire neighbourhoods and historic features of this great and ancient city constitutes a crime in itself, as does the looting and destruction of the precious relics of the Kabul Museum.

$5 \dot{68} \quad$ 


\section{Transitional justice and human rights in Afghanistan}

For the first time in the history of Afghanistan, as far as I know, rape became a regular feature of war. Factions killed captured enemies with a spike through the head or held them in the summer in sealed shipping containers, where they suffocated in the heat. Armed predators robbed civilians and subjected them to extortion. Outside Kabul, commanders often became lawless warlords, preying upon travellers and traders, abducting and raping young boys and girls, and profiting from smuggling and drug trafficking. Assassination became a regular means of settling disputes. Though the USSR had dissolved and the US disengaged, virtually every faction found a regional foreign backer that kept the weapons and money coming. Arab fighters from what we now know as alQaeda became increasingly prominent.

This was the context in which the Taleban emerged, as both an indigenous southern Pashtun response to warlordism and an instrument of Pakistani policy. The abuses of the previous period provided the justification for the Taleban's own harsh rule. They imposed the hudud punishments of amputation and stoning in the areas under their rule, and suspected opponents were dealt with harshly. The damage they wrought to the already fragile and debased education and health of Afghans through their obscurantist restrictions on women may not constitute crimes against humanity, but they deserve their own mention in this chronicle. The destruction of the Bamiyan Buddhas and as yet uncounted other treasures by the most extremist wing, allied with al-Qaeda, helped obscure the vast cultural destruction presided over by their predecessors.

For all this, the principal war crimes and crimes against humanity during this period occurred during the battle between the Taleban and various components of the opposition Northern Alliance for control of northern and central Afghanistan. The Taleban and al-Qaeda turned the plain north of Kabul into a ruined wasteland, executing some of the inhabitants, destroying the orchards and vineyards, and expelling the people. In the battle for Mazar-i Sharif, ethnic Uzbek and Hazara commanders of various Northern Alliance factions murdered

hundreds, maybe thousands, of Taleban prisoners in June 1997. The Taleban returned to kill many more thousands of civilians in August I998, including Iranian diplomats. Pakistani groups were implicated in these killings. Similar killings, if on a smaller scale, occurred as Bamiyan and Yakaolang in Hazarajat changed hands several times.

Taleban rule ended with the military campaign of the US and its allies after the attack of September I I, 200 I-itself a crime against humanity, and the only one of these that I witnessed personally, but one in which no Afghans were directly involved. After the fall of Kunduz to several factions of the US-aided Northern Alliance, including those recruited from the groups massacred by the Taleban in 1998, Northern Alliance commanders transported thousands of Afghan and Pakistani Taleban and al-Qaeda prisoners, who were told they would be released, towards Mazar-i Sharif. Some apparently suffocated in containers or were shot, to be buried in mass graves in the same area as the victims of 1997 and 1998. Others arrived at Qala-yi Jangi only to die in the suppression of an 


\section{Bamett R. Rubin}

insurrection under disputed circumstances, including bombing of the prison by the US and Britain. Some witnesses place US special forces or CIA officers on the scene of the killings.

Since that time hundreds, perhaps thousands, of civilians have died in US bombing raids, without public investigations or payment of compensation. The only trial-of pilots who accidentally killed Canadian soldiers, not Afghan civilians-resulted in an acquittal. Underground groups opposing the US presence have killed civilians in bombings in Kabul and elsewhere. The commanders of the Northern Alliance and others who returned with US and coalition assistance have established themselves in their areas again and are engaging in the same brutality in some areas as in the early I99os. Hazara and Uzbek militias have expelled Pashtun communities in northern Afghanistan, killing and raping the inhabitants, and violence and extortion prevail in much of the country. At least one prisoner has died under torture in government custody, and two members of the cabinet have been assassinated, in one case by members of the dominant faction, with no one charged or held accountable. Islamist extremists have asserted the right to execute Muslims for 'blasphemy' or 'apostasy' and have started to use such charges against their opponents.

Despite this history, or perhaps because of it, the voices calling for accountability for past abuses have been relatively weak and few. No one, to my knowledge, has proposed the establishment of a special court to try those responsible, though at least one commander, Abdullah Shah, has been tried in Afghanistan for his egregious abuses. Formerly known as the dog of Zardad, a commander of the Hizb-i Islami (Islamic Party) now in the process of being expelled from Britain, Abdullah Shah was caught chasing one of his wives down the street, trying to kill her. After he was gaoled other victims came forward.

In some post-conflict situations the peace settlement itself includes an agreement on transitional justice. In the case of Afghanistan, however, there is no peace settlement, as usually understood. The Bonn Agreement of 5 December 2001 was not an agreement among the warring groups to lay down their arms and build a new society. The parties did not painstakingly negotiate over a period of years how to structure a government that would resolve the conflicts that had torn the society apart, create new armed forces and a new police service, and confront the painful legacy of the past to lay the groundwork for national reconciliation. Quite the contrary: one side of the armed conflict, the Taleban and al-Qaeda, was still in the process of being pulverized by US bombs when representatives of four anti-Taleban groups convened in a hotel on a hilltop outside Bonn. They met there for ten days under extreme pressure, as a dentists' convention had reserved the same hotel after 5 December. These groups, together with the UN and major powers with a stake in the outcome, chose the ministers of what came to be called the interim administration of Afghanistan in the single night of $4-5$ December, before the sleepless UN Secretary-General's special representative, Lakhdar Brahimi, presided over a signing ceremony. Only one of the four Afghan groups participating, the Islamic United Front for 
the Salvation of Afghanistan (UF or Northern Alliance) had armed forces on the ground, and they were fighting the Taleban, not the other groups. Hence the political dynamic in negotiations between combatants who agree to a legitimate process to lay to rest in some way the charges each levelled against the other, as in South Africa or El Salvador, was absent in this case.

Nonetheless, the prospect of some reckoning with the past was on the mind of at least some delegates at Bonn, as well as those of the UN tean. One challenge that the latter faced was: who would be appointed to various offices? As one of Brahimi's advisers, I participated in discussions, and at one time suggested in a pre-Bonn discussion paper that no one guilty of war crimes, crimes against humanity or gross violations of human rights should serve as a minister in the interim administration. In discussions of the need to form new security forces, we noted the desirability of screening recruits, especially to the officer corps, to prevent the appointment of those who had committed serious abuses. These discussions came to naught: first, because no judicial or similar process was in place to determine who was ineligible, and it would be inpossible to obtain agreement on its mandate and establish a process with sufficient legitimacy in the time we had; and second, because the US-led coalition's policy of arming the Northern Alliance and other commanders as allies on the ground gave Afghanistan a de facto new set of armed forces without any such process. The creation of these armed forces based on the Northern Alliance still shadows all such efforts today and constitutes the major obstacle to forming a genuinely national army and police.

During the talks, the issue emerged again. The final text of the Bonn Agreement contains no reference to transitional justice, except for the establishment of the Human Rights Commission, whose mandate was understood, though not stated, to include coping with past as well as current abuses. Nonetheless, the issue did figure in the debates, as the UN drafters had included a paragraph stating that the interim administration should decree no amnesty for war crimes or crimes against humanity.

This paragraph forbidding an amnesty caused a furore within the meeting and an even greater one outside. The two members of the UF delegation from the party of Abd al-Rabb al-Rasul Sayyaf claimed that this measure was aimed at defaming the struggle of the mujahidin. We learned that the leaders of the UF were insisting to Muhammad Yunus Qanuni, the head of the delegation, that the paragraph be removed, and I overheard some rather heated discussions over Qanuni's British-supplied satellite telephone. In the drafting session, Mr Brahimi recalled to the delegates the danger of an amnesty. As he did several times during the negotiations, he referred to his own background in the Algerian struggle for independence. He reminded the delegates that a retired French military officer had recently published a memoir in which he had confessed to, even boasted of, his role in the torture and killing of Algerian prisoners during the war there. Yet because the French government had -declared a blanket amnesty, it was impossible to take any action against him. 
The resistance to the paragraph forbidding an amnesty for war crimes formed, part of a broader political struggle that defines part of the political context for today's decisions about transitional justice. Other items that caused conflict were:

- A paragraph drafted by the UN consisting of what we thought of as standard boilerplate for peace agreements, namely a call for demobilization, disarmament, and reintegration of unofficial armed groups; when some argued that it was dishonourable to call on mujahidin to abandon their arms, Brahimi once again referred to his past as a mujahid, noting that his decision to lay down arms and enter diplomacy was a good thing.

- Annex I on security, which called on the UN Security Council to authorize an international security assistance force for Kabul and, eventually, other areas.

- The role of the former king, Muhammad Zahir Shah, in the Emergency Loya Jirga (Grand Council) and, potentially, the government, and the lack of any mention of or role for Burhanuddin Rabbani, president of the largely fictive Islamic State of Afghanistan, which the Taleban had deposed and which still held the country's UN seat.

Rabbani and Sayyaf used these issues to mobilize support against the agreement. They told their followers that the purpose of the agreement was to ( $\mathrm{l}$ ) bring Western troops to Afghanistan through the invitation of the International Security Assistance Force; (2) to disarm and demobilize the mujahidin; and then (3) to try the mujahidin for 'war crimes'. International legal standards are not well known or understood in Afghanistan. The phrase 'war crime', janayat-i jangi, might be interpreted there to mean the crime of waging war, implying that all those who had taken up arms in the jihad could be tried.

Impending victory over the Taleban followed by a power-sharing agreement under US and UN sponsorship was causing anxiety among the fighters. Most international concern has rightly been focused on the women of Afghanistan and the civilian victims of the conflict, but the fighters, too, are victims. The young men fighting in Afghanistan in 2001, 23 years after the Sawr revolution, had known nothing but war and conflict their whole lives. They had been raised on and lived an ideology of jihad; they had never known a united Afghanistan where competing groups did not resort to arms; they had little education and few skills; and in the economy they had known, bearing arms, growing opium and smuggling seemed the only relatively lucrative professions. They might long for peace, but they also feared it. Peace might seem, if anything, less secure than war. Their commanders, some of whom stood to be the greatest losers in any peaceful settlement, could play upon these fears.

This point was brought home to me during the hours I spent negotiating the draft of a paragraph that now appears in the preamble of the Bonn Agreement, praising the 'mujahidin' for their sacrifices, and heralding their (as yet untested) determination to become heroes of peace and reconstruction. I remember the 
anxious face of my counterpart as he waited for us to finish the translation of the paragraph so he could fax it to Kabul. A top official of Afglanistan's National Security Directorate told me in Kabul in August 2002 that this paragraph was essential to winning the support of major armed groups for the agreement. Other concessions included the omission from the agreement of any explicit mention of disarmament or demobilization. Instead the agreement called for all armed groups to come under the command of the new administration and be integrated into national arned forces, which would be reorganized according to need.

Some time during the all-night negotiations necessary to clear out the hotel for the dentists, the paragraph forbidding an amnesty for war crimes was also struck out. Still, a year and a half after its installation, neither the interim administration nor its successor, the Islanic Transitional State of Afghanistan, has declared any ammesty for past violations. The goal was achieved without being explicitly proclaimed as a demand, something to bear in mind when making future policy recommendations about sensitive issues.

Similar political tensions were on display at the Emergency Loya Jirga in June 2002 , when a coalition of various mujahidin leaders pushed through a resolution changing the name of the new government from the Transitional Adninistration of Afghanistan, the phrase used in the Bonn Agreement, to the Islamic Transitional State of Afghanistan. Denunciations of warlords and warlordism, especially by women delegates, led Sayyaf to declare that criticizing mijahidin was equivalent to blasphemy, and hence deserving of death. President Hamid Karzai, despite his declared goal of eliminating warlordism, did not feel strong enough to abandon the policy of accommodation, and he included major regional commanders in his government.

During this same period, the discussion on transitional justice began, very slowly and tentatively. No major human rights organization, as far as I know, has called for the establishment of any special tribunal, international or mixed, to try war criminals in Afghanistan. All appear to accept that the situation is too complex and currently too fragile for such measures. The judicial system in Afghanistan is clearly incapable of exercising even the basic functions of legal order, let alone taking on a major task of historical accountability. The one trial of a commander that has taken place, that of Abdullah Shah, was based on ordinary criminal law. While the victims and their relatives welcomed the condemnation of the accused, the trial clearly failed to meet not just international but historic Afghan standards of fairness. In fact, there was hardly any trial. Asma Jahangir, the UN Human Rights Commission's Special Rapporteur on Extra-Judicial Killings, while welcoming the conviction, called for the revocation of the death penalty imposed on the grounds that the trial was unfair.

The Bonn Agreement placed the responsibility for transitional justice implicitly on the Independent Human Rights Commission, and during the preparatory process for its establishment, it convened a working group on accountability for past crimes. At the public meeting establishing the commission, President 
Karzai surprised those assembled by announcing that, while he did not know if it was within the powers of the interim administration to do so, perhaps the transitional administration that would follow it would establish a truth commission to investigate the past. At dinner at the palace on the New Year's festival, Nawruz, in March 2002, a minister suggested establishing a museum of the atrocities of the Taleban. Karzai rejected the idea, saying that the problem was not only the Taleban, but all the crimes of the past 23 years of war. At times he indicated to visitors that he wants to deal with this issue, and quickly; but by early 2003 he seemed to have settled on the message, as he told Lyse Doucet of BBC World News, that peace is a necessity and justice a luxury that Afghanistan cannot afford right now. He now says that his administration has taken a firm decision to draw a line between the present and the past.

The Independent Commission for Convening the Emergency Loya Jirga required candidates to sign a statement swearing that they had not killed innocent people or engaged in drug trafficking or terrorism; but this proved a hollow gesture with no enforcement mechanism. Many known to have violated those conditions served without obstacle. The cabinet ratified Afghanistan's membership in the International Criminal Court, to which spokesmen such as Foreign Minister Abdullah Abdullah, in another interview with Lyse Doucet, have pointed as a sign of Afghanistan's intention to fulfil its responsibilities under international humanitarian and human rights law. Once Afghanistan's accession takes place, on I May 2003, the ICC will have jurisdiction over war crimes and crimes against humanity committed in Afghanistan from that date onward.

A number of international human rights organizations have sent missions to sound out Afghans on the right approach to the past. Most have concluded that what Afghans need at present is the opportunity to reflect on and debate the issue in order to understand the variety of options that have been tried under different circumstances. The International Center for Transitional Justice, headed by Alexander Boraine, former vice-chairman of South Africa's Truth and Reconciliation Commission, has sent a small mission to work with the IHRC to help it think through alternatives and learn from international experience.

The main issue that has attracted attention to transitional justice in Afghanistan in the last year has been the discovery, or at least publicizing, of mass graves in Dasht-i Leili district in northern Afghanistan, apparently containing the remains of Afghan and Pakistani Taleban prisoners, as well as perhaps some al-Qaeda militants, captured by UF forces in the north-east Afghan city of Kunduz in November 200I. Their captors transported these prisoners in shipping containers, the ubiquitous sheet-metal boxes used for smuggling goods from Dubai and for building housing, shops and makeshift gaols throughout the country. At least some prisoners suffocated to death, and others may have been shot. The UF forces were then receiving assistance from US special forces and CIA operatives. Some witnesses assert that these Americans were present at the scene. Probably because of the charges of US involvement, these graves have received far more attention than others in the same region containing the 
remains of people killed in previous rounds of massacres, in I997 and I 998 . The local authorities, including General (now Deputy Defence Minister) Abdul Rashid Dostum, had promised to cooperate with investigations at that time, but the Office of the UN High Commissioner for Human Rights, despite repeated requests from Lakhdar Brahimi, then the special envoy of the Secretary-General, failed to push through those investigations, leaving a heritage of suspicion.

The organization Physicians for Human Rights, which participated in the preliminary forensic examination of those older graves, has also visited these newer sites. In April 2002, in confidential letters to President Karzai and key members of the Security Council, it called for the sites to be preserved. Although many observers consider him a chief suspect, Dostum claims he is guarding the sites, and UN political officers visit them regularly. As of early 2003 , they did not appear to have been disturbed. PHR, which has a track record of work on graves in this area and elsewhere, notably Bosnia, has undertaken a mission to the region on behalf of the UN High Commissioner for Human Rights and appears to have recommended caution, in view of the unsettled conditions and continuing conflict in the area. No major human rights organization has advocated making investigation into these sites the centrepiece of accountability in Afghanistan. Focusing solely on the recent past, and on particular cases with a political angle that contemporary politics makes attractive, risks defeating the purpose of transitional justice. For transitional justice must be not only just, but also fair. Justly calling perpetrators to account for certain crimes while ignoring others undermines the process, by making it seem captive to a political agenda. It may then reinforce factionalism and polarization, rather than reconciliation and peace. Above all, it may discredit the idea of transitional justice, making it seem a political tool.

Another proposal has come from Asma Jahangir. In her forthcoming report on Afghanistan, the UN Human Rights Commissioner's special rapporteur on extra-judicial executions has called for an international commission of inquiry, which could 'undertake ... a stocktaking of grave human rights violations in the past that could constitute a catalogue of crimes against humanity'. The commission would undertake a comprehensive catalogue of abuses since 1978 , not seeking to list every event or to attribute legal responsibility, but to establish a public, official record to be used as a benchmark in any effort that Afghans and the international community may undertake in the future.

Why is there so much consensus on caution? Sometimes people explain this by saying that one should not 'destabilize' the new order. Others respond that one should not stabilize an unjust order. The difficulty lies in the outcome of the activity: destabilizing the current order risks a return to the unjust disorder from which Afghanistan has barely emerged.

The injustices of the current order are clear, as is its fragility. Jahangir reports what others have also observed, that 'there is a climate of fear, and those who leak information on violations of human rights are threatened.' This climate of fear effectively prevents Afghans themselves, including the Independent Human 
Rights Commission, from seeking redress for current violations or pursuing transitional justice.

This problem of intimidation is merely one manifestation of a more pervasive problem, the one that nearly all Afghans identify now as their primary challenge - security. Security and human rights are often considered as separate problems: security as a problem for army and police, the 'security forces'; human rights as a problem for the judiciary, non-governmental NGOs, and, where they exist, official human rights commissions. In fact, security and human rights are the same problem. The main obstacle, or at least the immediate obstacle, to both in Afghanistan, as in other collapsed or failed states, is what Afghans call tufangsalari: rule by gunmen. In most of the country, regardless of the legal and constitutional structures established by the Bonn Agreement, effective power is in the hands of factional commanders who were armed by the coalition in $200 \mathrm{I}$. For most Afghans, that characterization includes the current ministry of defence, under Marshal Abdul Qasim Fahim. Most of these commanders were leaders in the jihad and the mujahedin government, but some, like Dostum, were former militia leaders of the communist regime. Some changed sides and also worked for the Taleban. Some of the commanders, and their followers, including both the major regional commanders often described as warlords, were those whose opposition threatened to derail the Bonn Agreement.

It would be wrong simply to blame these individuals and think that order and security would return to Afghanistan if the so-called 'warlords' and past abusers were removed from power. Key to this sentence, which I have heard so often, is the passive voice, indicating a lack of certainty as to who would carry out the task. More fundamentally, however, what will bring more peace and more justice to Afghanistan is not the removal of offending individuals, but the creation of a system of institutions to control them and make government effective and law-bound. Ending impunity by punishing offenders is part of that process, but it is neither the sole part, nor necessarily the first part.

The issue that will make or break virtually all others in Afghanistansecurity, reconstruction, human rights - is the disarmament, demobilization and reintegration of these former combatants, and the creation of a civilian administration and a system of law and justice. This in turn will require what has become known as the 'reform' of the defence ministry, a euphemism for removing it from domination by Fahim and his followers from the Supervisory Council of the North (SCN), founded by the late Ahmad Shah Massoud. Some former fighters will be integrated into the new Afghan National Army (ANA) or the police. Most will need alternative employment, and probably training, loans or grants, and other forms of assistance. Even more challenging will be finding alternative roles for the commanders, many of whom have used their weapons and men to seize houses, businesses and other assets. The war-disabled are already mobilizing in protest against the government, which has failed to carry out its modest promises of assistance. This is a mere foretaste of the problems that the demobilized could cause if they are disappointed.

576 
The government has assigned responsibility for both demobilization and the creation of the new security forces to a National Defence Commission, including major political and military leaders, among them the major 'warlords'. The US as the primary sponsor of the ANA and the UN as overseer of the entire process also play major roles, though the Pentagon has refused to allow US forces to participate actively in demobilization by acting as monitors.

The process of arriving at a common plan has sparked bitter debates. The major issue was the same one as at Bonn: how to reassure the hundreds of thousands of barely controlled, largely unpaid armed men that they will still have a future. The ministry of defence, controlled by the SCN, proposed a plan under which the base of the future army would be the mujahedin, mostly UF flohters, whose numibers would be gradually winnowed down. Those who were closer to the former king, or independent, argued for demobilization and disarmament of nearly all existing forces in favour of new ones created from those untainted by past battles and the unprofessional habits of guerrilla war. Though the debate was not conducted in the language of human rights, among the concerns raised by the latter group was the fear that the new forces would turn into a more efficient but still predatory group, which would abuse rather than protect the population. After being appointed at the Emergency Loya Jirga in June, Minister of Finance Ashraf Ghani trying to compel reduction in these forces, and refused to pay salaries for the 200,000 men Fahim claimed to have on his payroll, creating severe tensions in the government.

As one would expect, the process is marked by vast mistrust, delays, trickery, manoeuvring for position, and insecurity on the part of those eventually called upon to disarm. No one wants to give up his only source of livelihood or to disarm before his rivals or enemies do. But if this process fails, there will be no justice, transitional or otherwise, and no peace either. Afghanistan will remain a chaotic, misruled or unruled state, living, to the extent that it does, from narcotics and smuggling, and offering a free recruiting ground to all sorts of armed groups. But there is little intellectual challenge in spinning disaster scenarios for Afghanistan.

To argue that the success of demobilization, disarmament and reintegration (DDR) is essential, and, to the extent that there is a contradiction, that it should take priority over immediate measures to bring past abusers to account, is not to argue that 'peace' should take priority over 'justice'. Without successful DDR, Afghanistan will have neither peace nor justice. A state at peace is one where people have a reasonable expectation that justice may be done. Justice cannot be done in a state of war and collapse of institutions. Peace and justice are interdependent, not contradictory.

But in building institutions of governance after a conflict, it is important to carry out efforts in the right sequence. Elections before disarmament sparked renewed conflict in Angola and Cambodia, in the absence of legal institutions strong and legitimate enough to enforce the outcome. Of course, a political and social process is not like a machine that one operates by pressing the right 
buttons in the right order. People's need for justice and recognition of their suffering, and their pain and fear at being ruled by those who violated and abused them in the past, may erupt, as they did at the trial of Abdullah Shah. Most Afghans, however, seem to hope for the maintenance of today's fragile peace and stability, and the government's caution reflects their concern.

The danger is a repetition of what happened during the Bonn negotiations: that poorly timed external pressure for measures of transitional justice may lead the fighters or their leaders to connect disarmament and transitional justice, and conclude that, since the foreigners - the coalition and the UN-have come to Afghanistan to disarm the mujahidin and try them for war crimes, they need to keep their weapons for self-defence. Such fears did not ultimately manage to derail Bonn, thanks in part to intervention from the coalition, and similar intervention might keep spoilers in check in the future. But it could be all too easy for those who oppose the process to play upon such fears, especially in the charged political atmosphere of $2003-4$, with the debate over the constitution under way and elections scheduled for June 2004.

Yet one cannot simply postpone work on justice. The risks I have outlined are not certainties. They show how to be careful; they do not argue for paralysis. The US military states that it will carefully vet those recruited to the ranks of brigade commander and above in the ANA; those keeping records of who has done what in the past should watch over this process and assure that the new security forces, at the very least, eliminate the Abdullah Shahs. The Independent Human Rights Commission, with the help of others, should prepare a set of proposals for public discussion, bearing in mind that this will coincide with another potentially divisive and difficult discussion, that over the constitution. The panel of experts suggested by Asma Jahangir can be constituted and carry out its work in a low-key way. It need not interview victims in Afghanistan in a manner that would draw public attention to its work. So much has been documented, or alleged, in public documents over the past 23 years, that it could perform a service merely by collecting those records together into a coherent account that could constitute a public reference point once it is completed.

The president should clarify his own position and at least give a consistent message to his various interlocutors. He could ease some fears by issuing a decree declaring amnesty for all who have taken up arms for or against any Afghan government or political group since 1978 , with the exception of those who have perpetrated war crimes, crimes against humanity and genocide. He could take the opportunity to explain to the cabinet and public what those exceptions mean, while leaving it to the IHRC to propose how to deal with them.

I cannot say exactly what Afghans should or can do. If today's fragile peace holds and is further consolidated, the best option, in my view, would be a national documentation process that includes measures to clarify the fate of the disappeared and establish the truth about numerous massacres. - No one will ever make answerable the numerous foreign actors responsible for crimes of war, and

578 
this in turn will make it difficult if not impossible to pursue those Afghans responsible. Some, especially minor figures guilty of horrendous crimes, like Abdullah Shah, may eventually stand before the bar of common justice. If the process is comprehensive and fair enough, it may be possible to structure a process of recognition that allows those in positions of authority to admit their implication in serious crimes during the long decades of violence, in return for further participation and international legitimacy. If the coalition moves against some such figures, more will be possible, but at the risk of politicizing the process. It will never be possible to offer compensation to all the victims, or to punish those responsible.

It may be unfortunate if abusers retain their positions, but a process of accountability need not focus primarily on retribution. Actions are the result not solely of people's characters, but also of their circumstances. Some past abusers may change. Najibullah, though certainly a notorious violator of human rights, presided over major reforms in his later period in power. Many in Afghanistan remember him, at least in confidence, as better than any of the rulers who succeeded him. Removing this abuser from power did little or nothing to protect the human rights or security of Afghans.

Nor should we forget the tragic fact that 25 years of violence have left many brutalized and disturbed. I remember sitting outside in the clear winter sun of Peshawar with the late Anthony Hyman and Dr Muhammad Azam Dadfar in January 1989. Dr Dadfar, an Afghan psychiatrist who later participated as an observer in the UN talks on Afghanistan in Bonn and was elected a deputy chairman of the Emergency Loya Jirga, had set up the only psychiatric clinic for the three to four million Afghan refugees in Pakistan, a clinic he later had to close when it was attacked by extremists. I had helped Dr Dadfar obtain initial funding for that clinic from Amnesty International, in order to provide some treatment to victims of torture suffering from post-traumatic stress syndrome.

On that visit 1 saw the lines of those applying for treatment winding through the lanes of the Nasir Bagh refugee camp. Dadfar spoke of the vast range of psychological disturbance he had found among the Afghan population: in addition to the numerous torture victims, not only did a population of several million people have a proportionate number of schizophrenics and other 'normally' mentally ill people, but many refugees had persistent fantasies that their lost relatives would be found somewhere - in Russia, in prison, somewhere. Many suffered from intense suspicion, bordering on paranoia and sometimes crossing that line. Depression and sleeplessness were rampant, and increasingly angry and hostile fantasies prevailed, often acted out in violence against women or neighbours, or in war. The tensions between the sexes and generations over honour, pride and marriage that contributed to the Taleban phenomenon were already evident. The cycles of violence in places like Mazar-i Sharif, Bamiyan and Kabul were not merely political or ethnic in any simple sense. Many are enraged and disturbed by suffering, indifference, loss of honour, feelings of being wounded and of loss, which provide a pool of potential recruits for violent 
movements. I remember one of the wisest remarks I ever saw quoted from an official of the Taleban, Deputy Minister of Health Stanikzai. Protesting against the international isolation of his government, he asked: If a member of your family goes insane, do you punish him? Or do you try to heal him?

Afghanistan is a wounded society, and its people need healing, both as individuals and as a nation. We know that individuals cannot heal the wounds of the past by denying or suppressing them. One way or another, they need to confront them, in their own way, in their own time, when they are strong enough to do so, with the help of skilled and empathetic outsiders, and, in some cases, institutions of justice. If we are lucky, in Afghanistan the basic foundations that will make this process possible are just being laid; if we are unlucky, I do not know how the Afghans will survive. As the late Dr Muhammad Yousef, the first prime minister of Afghanistan's New Democracy in the 1960s, once said to me in support of a negotiated withdrawal of Soviet troops, the people of Afghanistan are not made of iron and steel. They are made of flesh and blood.

To those Afghans who are seeking that difficult way of reconciling their society with its past, we, the so-called international community, owe our support and, to the extent possible, our protection. We should provide that support in a way that advances the entire process of rebuilding order and justice in Afghanistan. It is too easy to make defiant statements from a distance and leave others to face the consequences.

It is also too easy to forgive offences committed against others. As we say in America, 'It ain't hard to get along with somebody else's troubles.' Islam, like Judaism before it, teaches that there are two types of sin: against God and against one's fellow human being. For the former, repentance before God suffices, but God will not forgive a sin against another until we seek that person's forgiveness ourselves. Afghans will have to decide how to conduct the lengthy and difficult process. Their culture and religion are replete with customs and traditions for reconciling disputes and wrongs, including murder, though the tribal rites of reconciliation between feuding clans were never meant to atone for the massacre and torture of thousands, of hundreds of thousands, of millions.

Struggling with these ambiguities lacks the moral clarity that I had when documenting violations of human rights and humanitarian law during the Soviet occupation. But the longer I have studied and lived with those crimes, the less I have been able to perceive them with the simple moral clarity with which I began. The discourse of transitional justice often sorts people into categories such as abusers and victims, but many in Afghanistan are both. I know a man presiding over a branch of an intelligence service that arrests and intimidates people who lost many of his own family to torture and assassination. Foreign intervention confronted the commanders of poorly equipped and undisciplined militias with the alternatives of capitulation or brutal, indiscriminate resistance. The collapse of institutions that provide security sometimes made violence seem the only alternative to victimization. Competition for desperately scarce resources led some communities to ally with warlords to wage war against one 
another. Najibullah, who once presided over the largest torture machine Afghanistan has known, was himself tortured, mutilated, murdered and exposed.

Caught up in the clash and fall of contending ideologies and empires, showered with weapons and money, prodded into and subjected to violence by vast forces beyond their control, and now, at least provisionally, sheltered by forces over which they have just as little control, Afghans have had few moments to consider how to remake their shattered and brutalized society. Despite our wishes, Afghanistan will not heal quickly from decades of violence. Let us help Afghans without pushing them, knowing that international support and protection are fickle and unreliable, and that Afghans will have to live with one another when recent arrivals have gone home.

The opening sura of the Holy Qur'an begins: 'Bismillah al-rahman, al-rahim; al-hamdu lillah, rabb al-'alamin, al-rahman, al-rahim; malik al-yawm al-din. Iyaka na'budu wa iyaka nasta'in. Ihdina al-sirat al-mustaqim.' 'In the name of the Merciful, the Compassionate: praise be to God, the Ruler of the universe, the Merciful, the Compassionate, Master of the Day of Judgement. You do we worship, and on You do we rely; show us the right path.'

One can interpret these words in several ways. The attribute of God's rulership is preceded and followed by two attributions of mercy, and the attribution of judgement comes only after those four attributions of mercy. On the other hand, even after four attributions of compassion, judgement still follows. And the invocation ends with a humble prayer for guidance. Whoever wishes to help the Afghans recover from their decades of violence might invoke these words at least five times a day. 